\title{
THE ROLE OF WAR GAMES IN THE OPERATIONAL PLANNING PROCESS
}

\author{
Radiša Saković and Vlada Mitić \\ Republic of Serbia, Ministry of Defence, Defense Policy Sector, \\ Strategic Planning Department \\ Mitar Kovač \\ Edukons University, Faculty of Project and Innovation Management, \\ Belgrade
}

Qver the past several decades, most regional and local conflicts have merely been the scenarios prepared in advance in the "kitchens" of great powers. The aforesaid scenarios are practically tested on simulation-based models that are formed as war games, which considerably save resources and improve the strategic and operationaltactical planning process.

Information technology has had the decisive impact on the development of war games resulting in the fact that various software packages have been developed, as well as the systems which provide support to commands and $\mathrm{HQs}$ in a decision-making process at all command and control levels. The findings showing that resources can be rationally exploited and financial funds considerably saved indicate the efficiency of applying war games in the operational planning process and cause specific simulation-based models to be developed in commands and HQs of modern armed forces.

The aim of this paper is to point out the role and importance of war games in the operational planning process. To that end, various models of war games have been analyzed, along with the possibility of applying them in the operational planning process and activities conducted by the commands and HQs of the Serbian Armed Forces. The paper examines the disadvantages of models that have already been applied in the drill of the Serbian Armed Forces units, at the same time indicating the modern models of war games. The topic has been addressed through four items: 1) the term and characteristics of war games; 2) the elements of war games; 3) the structure of war games and 4) the application of war games in the operational planning process.

It has been concluded by the research results that war games are an integral and inseparable part of the operational planning process in modern armed forces and that they are implemented as various models for making decisions during the preparation and execution of combat actions and armed conflicts. The collected findings have shown that war games are an integral part of the operational planning process in the Serbian Armed Forces too, as well as that the level they have reached is not satisfactory and should be improved by being more comprehensively imple- 
mented in commands and HQs, provided that automated command-information systems have previously been established. Ensuring that the above-mentioned conditions are met at all command and control levels would contribute to introducing a decision-making support system in an organized manner and improving the efficiency of the operational planning process, and thus making timely decisions while conducting missions and tasks of the Serbian Armed Forces.

Key Words: War Games, Commands and HQs, Operational Planning, Conflicts

\section{Introduction}

$\Lambda^{t}$ the beginning of this century, many countries experienced rapid economic growth which was driven by numerous achievements made in science and technology, and first of all, in the field of information and technology. The economic growth was mainly driven by achievements made in the military industry, especially at the time of the division into blocs, and the arms race of the world's most developed countries. The situation like this resulted in a need to strengthen the function of strategic planning, and to permanently analyze the opponent's capabilities in order to come up with warfare models which would give commands and units the initial advantage and provide better conditions for operational development. The actual testing of models by implementing real exercise-related activities required the employment of considerable human and material resources along with enormous financial expenses, which resulted in a need to develop simulation and create war games.

War games were made on the grounds of the game theory and were primarily developed within military sciences in accordance with the scenarios made by possible belligerents. Most research on basic concepts of the game theory and structural elements of war games is based either on looking for answers to some military and security-related questions or finding solutions to specific simulated conflicts (for example: the Battle of the Bismarck Sea, the Game of Intimidation, the Game of Deterrence (Mukić, 2014).

In the Serbian Armed Forces, war games are generally applied in the decisionmaking process while preparing and conducting tasks from the first Mission, which refers to the defense of the Republic of Serbia from the armed threats. Depending on the purpose and type of commands, the decision-making process follows the standard operating procedures where all phases and steps of the operational planning process have been implemented in accordance with the relevant instructions and standards and criteria that have already been set up (the General Staff of the Serbian Armed Forces, 2017).

The experiences gained by commands and HQs of the Serbian Armed Forces in applying war games in the operational planning process indicate that war games have been insufficiently, inadequately and very often superficially applied, especially by the army branches, which do not take them into consideration at all. In order to successfully eliminate shortcomings, it is necessary to observe the role and importance of war games, as well as the possibilities for procurement of new software solutions and introduction of the already existing ones all the way down to HQs of the lowest tactical units, which will make it possible for command staff to be trained during preparatory activities and execution of all actions and counteractions. 
If the systematic approach to the development of war games is applied in order to enhance the operational planning process in the Serbian Armed Forces, the conditions will be made for applying new operational methods in commands and $\mathrm{HQs}$ and more successful standardized procedures. By attributing greater importance to war games in the Serbian Armed Forces, a comprehensive approach to the operational planning process would be made possible, and thereby timely decisions would be made at all command and control levels.

\section{Concept and Characteristics of War Games}

Over the course of history, military sciences have constantly advanced, striving to be fully developed and following, in doing so, the other social and liberal arts, technicaltechnological and other types of sciences, including all their constituents. ${ }^{1}$ The greatest problems in defining military sciences and their scientific disciplines have arisen while selecting the methods of military sciences and laying their foundations, where war games have very often been, as a matter of priority, discussed to be the only possible and the most eligible solution. The selection of the accredited methods of military sciences has been addressed by a lot of foreign and national authors, where the greatest achievements have been made with reference to theoretical development of tactics and operational art (Liptai, 1996).

War games were derived from games, which people find entertaining and which contributed to introducing people to each other, making them closer and outsmarting each other, with no intention of inflicting losses, injuries, etc. to the opposing party, but with the aim to win by making higher-quality decisions. The situations in which interests of two or more parties are entwined, confronted or conflicted are called conflicts. That is why we often say that the parties which make decisions are in a conflict. For example, in the game of bridge, the result of the game does not depend only on a move of one player, but of the other, as well. Their interests are in a conflict because both parties want to win.

This concept of a game is impossible to apply when various governmental and nongovernmental stakeholders have the same interests, and are ready to exercise not only political and military, but also regular and irregular forms of strength and power. Bearing in mind that in each conflict losses are inevitable due to diametrically opposite goals of adversaries, a war game is a mechanism for testing the strength and in doing so its duration and intensity directly depend on the quality of the decision made. In some cases, the consequences of the decision being made depend only on one party, as it is the case when a commander makes a decision which route should be used by a unit to move in the operation of preventive deployment of forces. However, the most frequent decisions are the ones whose the consequences do not depend on one party only, but also on the decisions made by the other party, as well, which is particularly typical for armed conflicts.

By experience, it is well-known that the bloc-divided countries and the leading world powers have different approaches to the interpretation of war and the definition of the concept and categories of armed conflicts, which is particularly characteristic for the be-

\footnotetext{
${ }^{1}$ Science constituents: subjects, theories, methods and language.
} 
ginning of this century with the emergence of hybrid threats and asymmetric forms of conflicts. Such a situation resulted in having different approaches to the perception of war games, particularly with reference to their concept. The available facts have shown that a great number of authors think that the equipment makes a key element in war games, while not so many authors think that a human element is a decisive factor.

Generally, a war game is a model trying to present an armed conflict as real as possible through a descriptive and prognostic character (Radinović, 1983). In this respect, the previous, already waged conflicts can be modelled by war games, which, in that case, mainly have a descriptive character, or some future conflicts which, generally, have a prognostic character. The descriptive character of war games is used to confirm the long-time practical experience or to explain the knowledge gained in the previous period. The prognostic character of war games emphasizes that war games are focused on the prediction of outcomes in the modelled conflicts by introducing various variables, as well by evaluating their effects, so that scientific conclusions can be made.

War games are characterized by specific attributes or properties which are based on the attitudes gained by experience and the results obtained in the process of confronting capabilities between the opposing parties (players). These characteristics are based on the impartiality of a war game and avoidance of the subjectivity by commands and HQs, because the information collected should not reflect the commander's wishes, but the facts which reflect the real situation and create a clear operational picture of the battlefield. War games are most often characterized by a lack of relevant intelligence information, uncertainty in estimating the situation and the risk in predicting our own and the opponent's future steps. Apart from the above - mentioned characteristics, there are a lot of others, as well, which primarily refer to the insufficiency of the strength and assets, i.e. the limitations in human and material and, quite often, spatial and time resources.

Bearing in mind the technological progress, as well as the rapid development of information technologies and their growing presence in modern armies, war games are gaining more and more importance in the operational planning process, despite the various attitudes with reference to their characteristics and concept. The above - mentioned trend will lead to the conditions in which war games will not be applied only for solving operational combat tasks, but also for solving tasks of civil defense, emergency management and other security-related fields.

\section{Elements of War Games}

War games have evolved through history and they are widely used in other fields, as well, not only the military one. Nowadays, there are war games developed for entertainment (hobby war games), as well as professional war games, which are used solely in the military field (Perla, 1990). There is a large number of examples of war games, which have been developed for entertainment (a hobby), and which imitate historical conflicts with great accuracy of the final outcome (Figure 1). Thus, a lot of hobby war games have a descriptive character with the aim to bring armed conflicts from the past closer to a huge audience of players. 

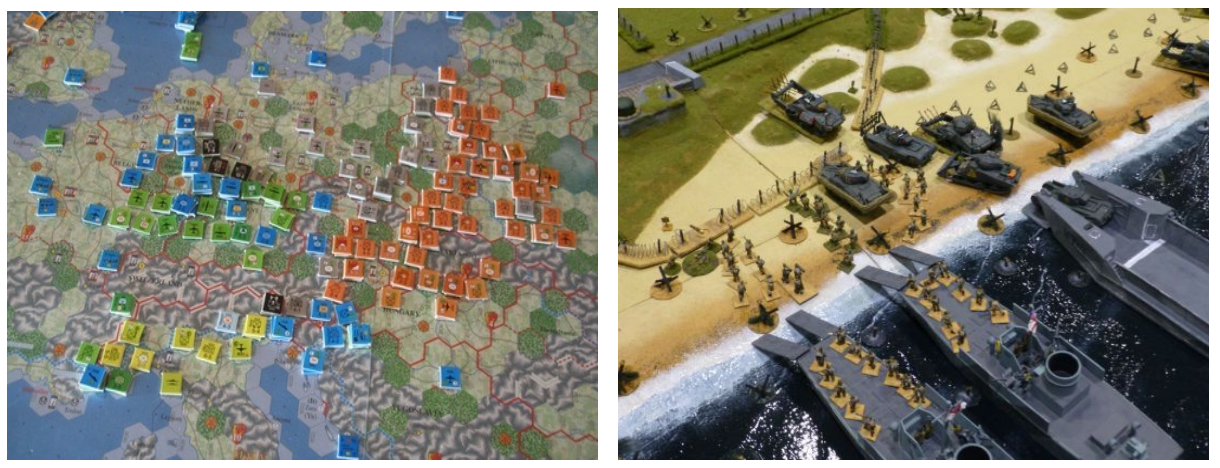

Figure 1 - Examples of hobby war games: left - the strategic war game of World War II World in flames; right - the war game Flames of War: the Battle of Normandy in World War II (Salute 2014 - World War II)

The expansion of hobby war games has brought about the development of professional war games, but the tools and rules of hobby games are adjusted and used for the improvement of professional war games (Perla, 1990).

The necessary elements of a war game, generally, are: goals, scenario, database, players, rules, models (simulation) and analysis (Figure 2).

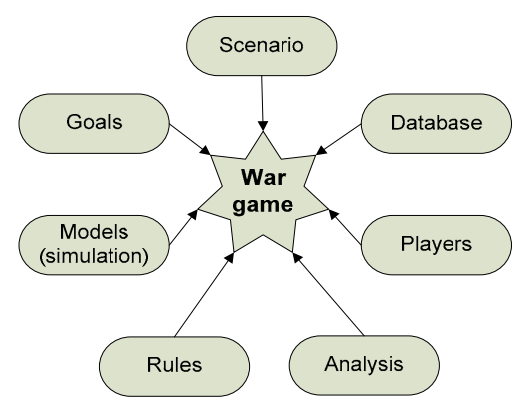

Figure 2 - Elements of war games (taken, adapted and designed

(Perla, 1990: United Kingdom Ministry of Defense, 2017)

Goals of war games should be focused on collecting experiences and information required for conducting various processes related to security of countries, so that the desired situation is achieved. For example, during the operational planning process, the goals of a war game are set up in the phase of identifying required strength and assets, by means of which all conditions are provided for conducting the assigned missions and tasks. That is how the goals become guidelines for creating the game, and particularly for guiding players in the game. ${ }^{2}$

\footnotetext{
${ }^{2}$ Red player(s) will have their goals and blue player(s) will have different goals. Moreover, the goals of other actors can appear in a war game.
} 
A scenario of a war game is a specific situation in which the players are placed and which has a decisive impact on all war game factors (Perla, 1990). The scenario can result from previous steps of the environment analysis and scenario development, i.e. classified and grouped factors from the environment, which have a decisive impact on a war game and their possible values. Furthermore, the scenario can be a product of the future steps of the environment analysis and scenario development, i.e. selected, interpreted and analyzed scenarios, which have been developed at a higher level $l^{3}$. In terms of hierarchy, high-level scenarios are the product of the morphological analysis-based methods and high-level war games. This is how the integration of the morphological analysis-based methods and war games has been established, being two techniques of the scenario development which complement each other.

A database comprises the information which players need to know, so they can make decisions while playing a war game (Perla, 1990). The database needs to have information on key factors and their values, as well as on some planning process products, and especially on analyses of adversaries and interested parties, analyses of strategy, concept and legal framework, as well as the identification of required capabilities and option development for achieving the required capabilities. In regard to key factors and their possible values, the selection of factors will, to the greatest extent, depend on the level of operations execution (Table 1).

Table 1 - Types of factors found in the database with reference to the level of war games (Weiner, 1959)

\begin{tabular}{|l|c|c|c|c|}
\hline \multirow{2}{*}{$\begin{array}{c}\text { Types of factors involved in a war } \\
\text { game }\end{array}$} & \multicolumn{4}{|c|}{ Type (intensity) of a conflict } \\
\cline { 2 - 5 } & Duel & Battle & Campaign & War \\
\hline Resources & $\mathrm{X}$ & $\mathrm{X}$ & $\mathrm{X}$ & $\mathrm{X}$ \\
\hline Objectives & $\mathrm{X}$ & $\mathrm{X}$ & $\mathrm{X}$ & $\mathrm{X}$ \\
\hline Military intelligence information & $\mathrm{X}$ & $\mathrm{X}$ & $\mathrm{X}$ & $\mathrm{X}$ \\
\hline Environment characteristics & & $\mathrm{X}$ & $\mathrm{X}$ & $\mathrm{X}$ \\
\hline Background information & & $\mathrm{X}$ & $\mathrm{X}$ & $\mathrm{X}$ \\
\hline Logistics & & & $\mathrm{X}$ & $\mathrm{X}$ \\
\hline Economy & & & $\mathrm{X}$ & $\mathrm{X}$ \\
\hline Psychology & & & $\mathrm{X}$ & $\mathrm{X}$ \\
\hline Politics & & & & $\mathrm{X}$ \\
\hline Other parties & & & & $\mathrm{X}$ \\
\hline
\end{tabular}

In the low-intensity conflicts based on war games, such as duels, which consider a platform-to-platform situation, the factors describing the platforms themselves are important (for example: a number, tactical-technical characteristics, performances, etc.), as well as the objectives of each of those platforms and the basic intelligence information, which players should have about each other (Weiner, 1959) (for example: possible locations, the time of opponent's actions, the battle order, organization, support, etc.). The battles, which are

\footnotetext{
${ }^{3}$ Since the design of scenarios by using war games is, to the greatest degree, created for the purpose of the conflict scenario, higher level scenarios can be scenarios of the environment, threats and strategy.

${ }^{4}$ The break-up of conflicts by types (intensity) can be different, for example: by forms of combat operations, such as a fight, battle or operation (the Federal Secretariat of People's Defense, 1981); or by levels of objectives which have to be reached, at tactical, operational and strategic level (Djordjevic, 2012; General Staff of the Serbian Armed Forces, 2012).
} 
high-intensity conflicts in war games, should, along with the aforesaid information, involve the background information, as well as the environment characteristics (Weiner, 1959). Campaigns, which are reviewed much longer than battles, should include the important information referring to logistics, economy and politics. War, as the highest type of a conflict, must include the information on political factors and other parties involved in war.

Models of war games are designed to transform the database data and players' decisions into events in a war game (Perla, 1990). While making a model, the following recommendations should be taken into consideration (Perla, 1990): the model flexibility, accuracy and uncertainty. Due to the complexity of war games, design of war games requires a combination of various models in order to increase the impartiality and reality. The selection of models, to the greatest extent, affects the establishment of war games rules. The theory of war games includes the following models (Weiner, 1959): mathematical, mechanical (computer-aided simulation), board games and umpired models.

Mathematical models imply that various mathematical models are applied and combined for the needs of war games. The application of mathematical models begins, in principle, with the methods of game theories (Weiner, 1959; Kahn \& Mann, 1957), which later build on the mathematical methods for calculating the outcome. Mathematical models are based on developing and linking possible player's actions, as well as on using the data on the value factors from the database related to the characteristics of the strategy applied by both players, so the conflict outcomes can be calculated by applying the mathematical tools (Figure 3).

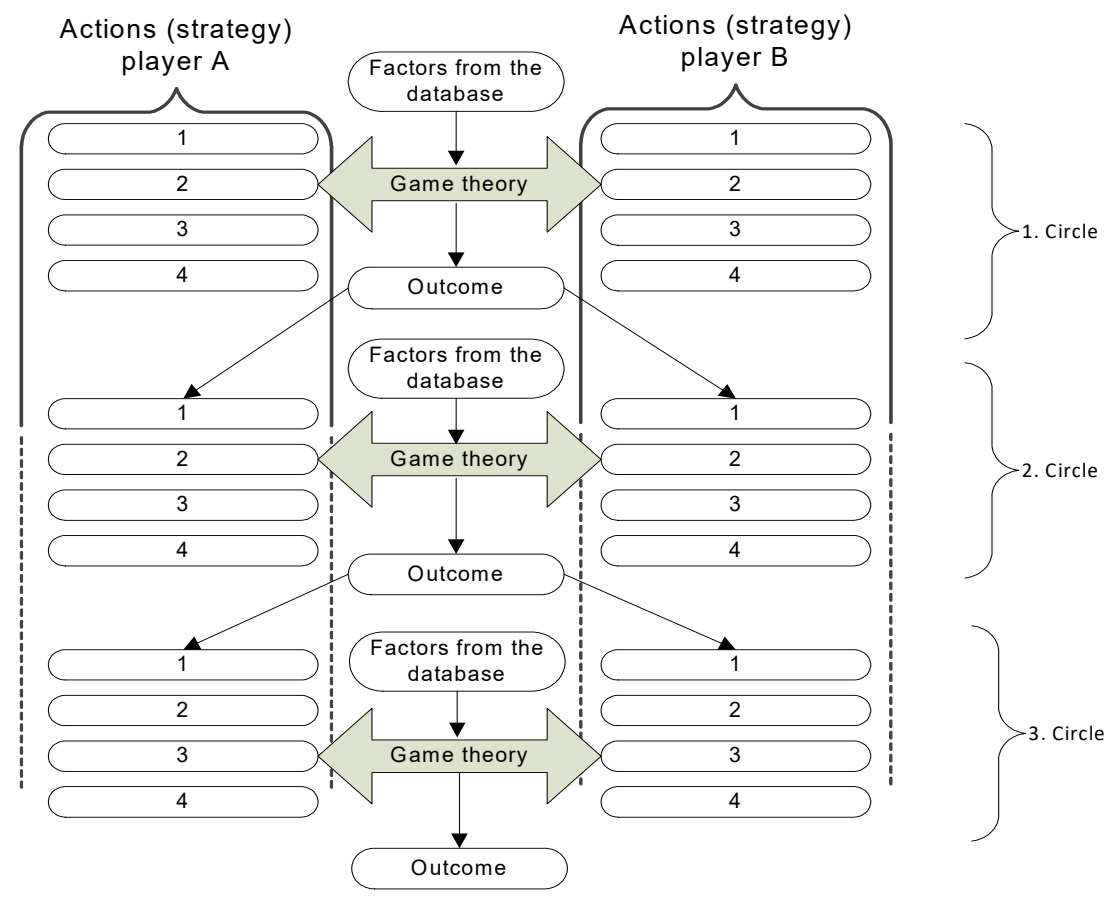

Figure 3 - Mathematical model of war games - taken and supplemented (Weiner, 1959) 
By applying the methods which are based on the theory of games, the actions of one side are related to the reactions of the other side, so the form matrix of "the strategy of the player A" and "the strategy of the player B" is established, which presents a circle of the game (Weiner, 1959). Various combinations of strategies, i.e. actions taken by both players in one move will result in different outcomes ${ }^{5}$. The outcomes obtained should be in accordance with the required effects determined in the phase of identifying the required capabilities, so the war games are used to determine if some activities being implemented result in the required effects. The outcomes from the first circle have an impact on forming new strategies for both sides, the outcomes from the second circle affect the strategy for the third circle and it continues until one of the sides achieves the objectives. Professional war games are most often played by making sequential moves, such as action-reaction-counteraction ${ }^{6}$ (General Staff of the Serbian Armed Forces, 217), i.e. the circle is made up of three moves made by players (the actions made by players $A$ - the reactions made by player $B$ - the counteractions made by player $\mathrm{C})^{7}$ (Figure 4 ).

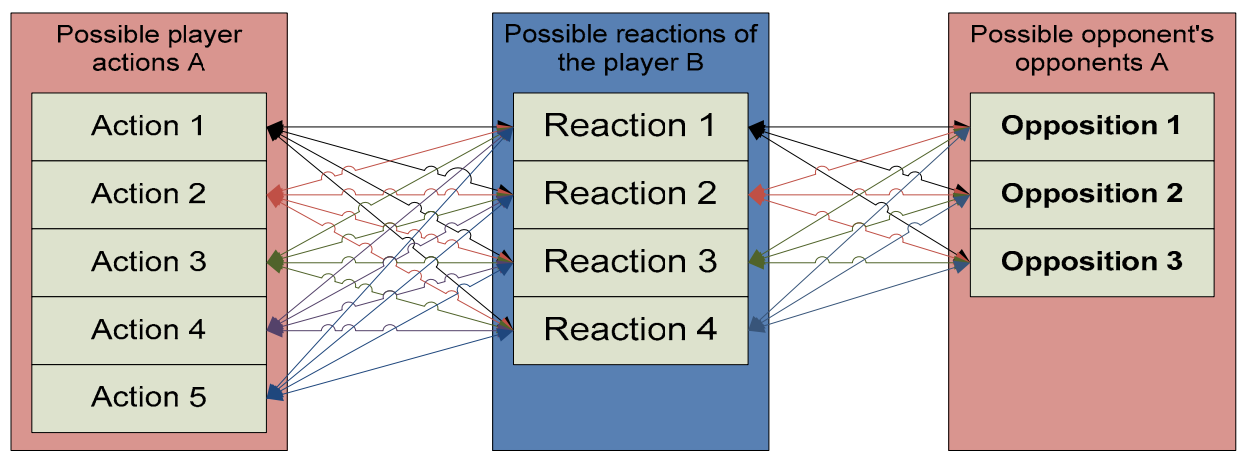

Figure 4 - Possible movements made by players in one circle of a war game - taken and supplemented (Morgan, McLeod, Nixon, Lynch, \& Hura, 2018)

Every possible action of player $A$ should be related to every reaction of player $B$, while every reaction of player $B$ should be related to every counteraction of player $A$. Each of possible action-reaction-counteraction combinations in one circle needs to be

\footnotetext{
${ }^{5}$ The outcome provides the following information: if the player A plays strategy 1 , and the player B plays the strategy 2, it will happen that... for example the player A makes $x$ and player B makes $y$ losses, etc.

${ }^{6}$ Actions of a player (actions-reactions-counteractions) are identified in the phase of identifying the required capabilities, but war gaming itself helps them to be identified, so a required parallel bond is obvious between the phase of identifying the required capabilities and the phase of analyzing the environment and scenario development, particularly in the domain of war games.

${ }^{7}$ Taking the objectives of war games into consideration, the player A can be either red or blue, which depends on the scenario, rules and objectives of a war game, but the red player is most often in the role of the player A, and the blue player in the role of the player B. Moreover, the sequence of players defining who of them makes the first move can be changed from one move to other, so one move can begin with the blue player, the second one with the red player and the third one with the blue player again.
} 
evaluated from the point of factors which have the key impact. It can be seen that such a structure of actions taken by both players makes it possible for the morphological analysis to be used, so relevant morphological fields are here complemented with possible actions-reactions-counteractions. The morphological analysis can be used to test the possible intercompatibility (consistency) of the actions taken by both players, as well as the compatibility of the actions with key factors from the environment. The results of the morphological analysis can complement war games. That is how a parallel bond can be established between the methods based on the morphological analysis and war games.

Numerous mathematical methods have been developed and applied so far for calculating the outcomes. Since actions taken by both parties in one move put their resources in the interrelationship of conflicts, the mathematical methods based on the combat dynamics can be applied, i.e. Lanchester's equations, as well as more simple and practical models of calculating combat possibilities (Kovač, Dulanović, \& Stojković, 2006; General Staff of the Serbian Armed Forces, 2015).

The mathematical models based on the combat dynamics take into consideration tactical-technical characteristics of platforms ${ }^{8}$, the environment, as well as the information and assumptions about the conflict expressed by military intelligence information, on whose basis, they, by certain mathematical equations, calculate the outcome as the degradation of a specific platform, i.e. losses made by a party in a game (Przemieniecki, 2000), as in the case of the conflict of infantry units (Mitić \& Petrović, 2015), unmanned anti-armor aircraft and armored personnel carrier (Petrović, Mitić, \& Mudri, 2015), etc. The above - mentioned methods require a great number of experts from the field of mathematics and various military sciences to be involved. The mathematical models are not applied sufficiently in the Serbian Armed Forces because the methods based on the combat dynamics are not adjusted to be used by commands and HQs during the operational planning process, but they can be the good ground for the development of methods which are based on combat capabilities. On the other hand, the methods based on the calculation of combat capabilities take into account the same input data as the methods based on the combat dynamics, with the only difference of having simpler mathematical tools, which are based on the possibility of destroying the opponent, as well as on modifiers, i.e. coefficients of probability of decrease and increase, which depend on the environment where the conflict takes place $^{9}$. The introduction of modifiers makes the calculations easier and enables the models based on combat capabilities to be used by commands and staff during the operational planning process, but the accuracy of the final outcome is lower than with the methods based on combat dynamics.

It can be concluded concerning the mathematical models that the measurement of outcomes is based on deduction, which can be presented as the if-then function:

$$
\text { if }([\text { action } \mathrm{A}] \wedge[\text { reaction } \mathrm{B}] \wedge \text { [counteraction } \mathrm{A}]) \Rightarrow \text { [outcome] }
$$

\footnotetext{
${ }^{8}$ Hit probability, rate of fire, radius of action, penetrability, range, rate of movement, kinetic protection, etc.

${ }^{9}$ For example, modifiers that reduce or increase the likelihood of destruction due to the effects of morale, capability level, terrain, the use of chemical and biological weapons, degree of preparedness, degree of land development and fortification and the like (General Staff of the Serbian Armed Forces, 2015)
} 
Machine war games or computer-assisted simulation are based on the use of information technology and a game. Machine games have a database and maps relevant for war games and they use mathematical models in order to calculate the game outcome. All mathematical operations required for a game are processed by a computer according to previously set algorithms. With reference to machine war games, the following types of games can be distinguished according to the criterion of players participating in the war game (Weiner, 1959): machine-machine, machine-man and man-man war games.

A large number of computer-assisted war games have been developed so far, both for entertainment and professional purposes related to planning operations and conducting military exercises. Along with the computer simulation, a live one-sided or two-sided exercise can also be conducted by completing the war game database with the information ${ }^{10}$ gathered in the field during the actual exercise (Sennersten, 2010), thus achieving the greater objectivity in the execution of the war game.

In the Ministry of Defense and the Serbian Armed Forces, the machine- (computer-) assisted war game of JCATS type is applied (Lawrence Livermore National Laboratory, 2018) - Figure 5. The JCATS software runs on the Linux operating system and represents a multi-sided, stochastic and interactive high-resolution simulation designed to model the interaction of forces, from joint forces to individual platforms. In JCATS software, players-users have different visual displays of JCATS during the simulation.
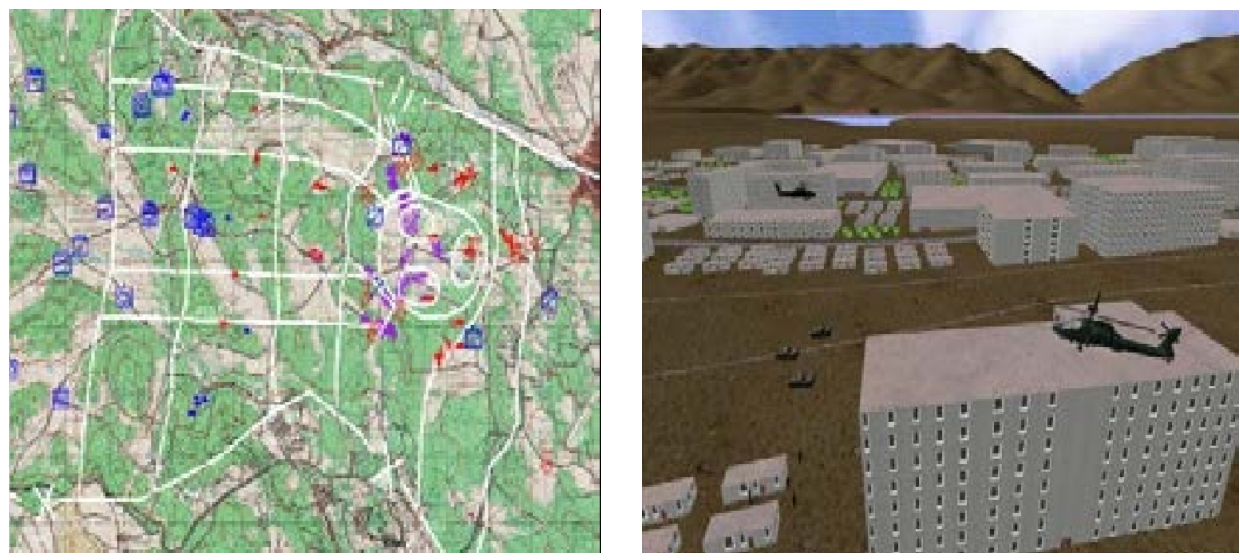

Figure 5 - Examples of possible JCATS war games (Lawrence Livermore National Laboratory, 2018)

\footnotetext{
${ }^{10}$ Information on the exact situation in the field can be entered in the computer war game either manually or automatically by using the telecommunication-information devices together with the devices for navigation, locators, fire and hit simulators and the like.
} 
JCATS visual presentation is a physical model that includes all the parameters of the digital military topographic map (Military Geographical Institute, 2016) ${ }^{11}$, as well as the database related to the characteristics of the combat platforms available to the players. The connectivity with the database ensures the accuracy in simulating reconnaissance and observation, as well as the accuracy of data collecting sensors, weapons systems, ammunition, vehicles, not only on the ground, but also at sea and in the air, as well as the connectivity with the real command-information systems (Lawrence Livermore National Laboratory, 2018). Based on the software algorithms, which are founded on mathematical models, the effects of the conflict are calculated and presented, which allows the examination of different decisions in the planning process.

Board war games are the most common model of war games that is implemented in military practice, especially because of its price and ease of production and use. The elements of board war games are most often a map (a board) or a topographic map of a certain scale, unit markers (Weiner, 1959), and often a grid that is placed over the map (Figure 6).

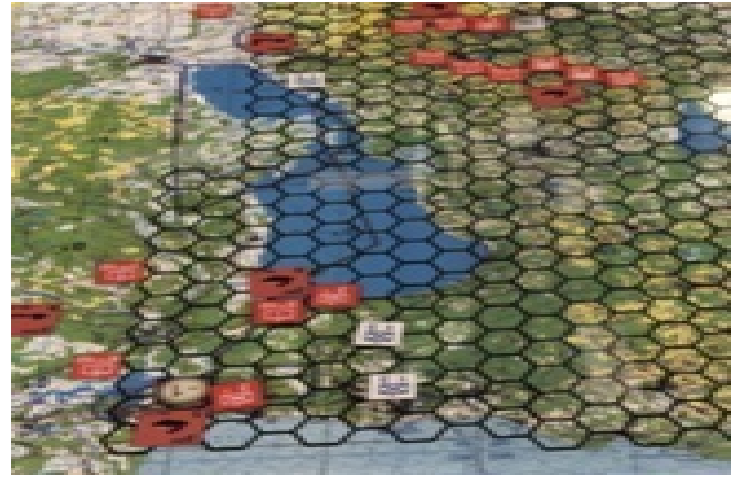

Figure 6 - Example of RAND war game elements with the map, grid and unit markers - taken (Shlapak \& Johnson, 2016)

The maps used for playing war games can be topographic or relief maps of various scales (Military Geographical Institute, 1971-2001), which correspond to the area, where the combat operations are planned to be conducted, while the scale corresponds to the level of performance of the operations. Unit markers are most often two-dimensional cards made on cardboard, paper, plastic or other materials, and different types and levels of units are marked in accordance with the Instructions for Operational Planning and Work of Commands (General Staff of the Serbian Armed Forces, 2017). The grid is a transparent layer placed over the map, and it is recommended that it has a hexagonal form to allow the establishment of motion rules and actions of units in all directions, as well as the simulation of support to adjacent units (Figure 7$)^{12}$.

\footnotetext{
${ }^{11}$ For example: digital maps of the Military Geographical Institute (Military Geographical Institute, 2016).

${ }^{12}$ Unlike the quadrangular grid that allows forward-to-left-to-right directions.
} 


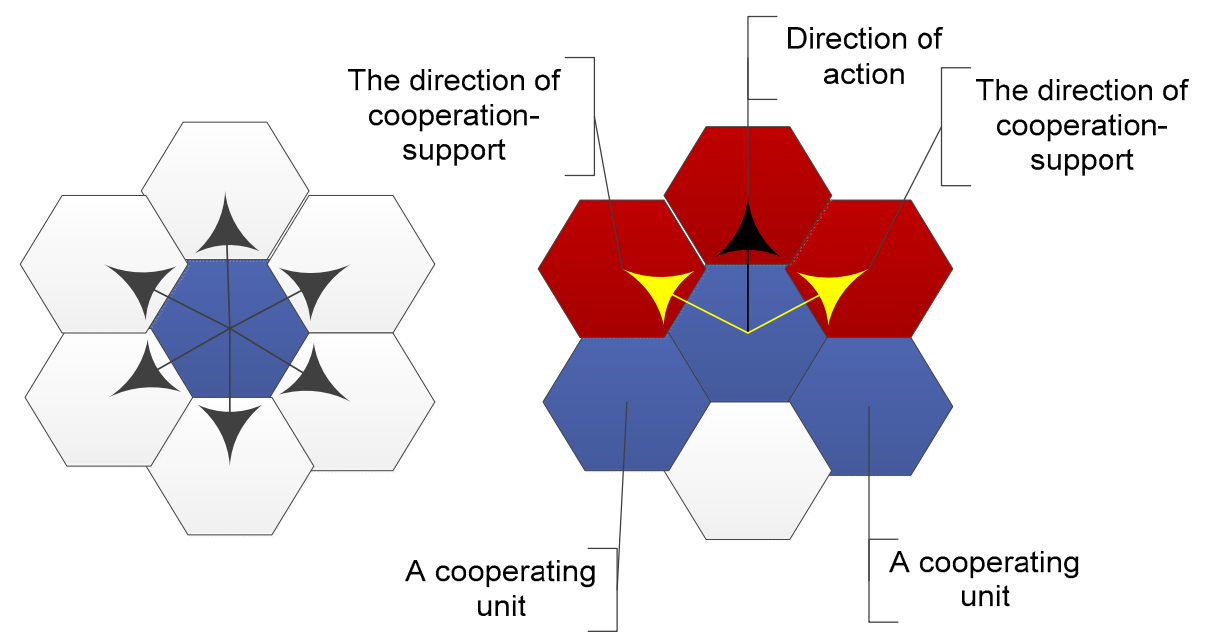

Figure 7 - Example of the use of the hexagonal grid: left - possible directions for the movement of the blue player; right - possible directions of action and cooperation - support of the blue player

The players in board war games are people, where there might be one man, teams or units at each side. Unlike machine games, players have countless possible actions they can take at their disposal (Weiner, 1959). Playing board war games is not possible without previously applied mathematical models, which establish the rules of board war games, and the calculations of combat capabilities are of particular importance.

Umpired war games are based on the assessment made by an umpire on the outcome of a player's actions. Umpires are usually the oldest and most experienced officers in commands-HQs. This type of games is applied when clear rules of the game are not elaborated, when there are no mathematical models that are used and when there is a lack of time as a resource (Weiner, 1959). The shortcoming of these games is subjectivity that can influence the assessment of outcomes, and give wrong information. Taking into account the practical experience gained on war games in the Serbian Armed Forces, which are described in the Instructions for Operational Planning and Work of Commands (General Staff of the Serbian Armed Forces, 2017) it can be concluded that although they are played on the map, these war games belong to a group of umpired war games due to the vaguely defined rules, as well as due to the assessment of the outcome made by umpires.

Rules are the next element of a war game that needs to be determined during the design of the war game. The choice of different models of war games will imply different rules, so the development of rules goes on concurrently with the selection and development of war game models. The purpose of rules in war games is to: dictate which models will be used and when; establish rules of connectivity between action, reaction and counteraction; provide the delivery of necessary information to players, as well as possible mistakes in information in relation to their reliability; determine the roles of players in a war game and the like (Weiner, 1959). 
By analyzing a large number of sources dealing with rules, both professional and hobby war games (Exercise Aldershot Skirmish, 2016; Martin, 1982; KDV Technology \& Consulting, 2004-2018; United Kingdom Ministry of Defense, 2017; McHugh, 1966; War games research group, 1972; First Battle Basic Rules, 1989), it can be concluded that some of the main rules of war games are based on the identification of the following elements:

- the flow of time, which regulates how long the cycle lasts and what the ratio of past time and movement by the coordinate system is;

- game sequences that regulate which player plays first and when, how many moves there is in one circle, and when the outcome of the circle is calculated (either after each move or when the circle ends);

- the size of the base because it specifies how much space on the map in relation to the grid elements a certain unit type and size occupies;

- detection radius and detection radius modifiers; ${ }^{13}$

- movement and movement modifiers, which define the rules of movement and regulate how many elements of a coordinate system a certain type of unit can pass in a unit of time, while modifiers change the number of possible elements of the coordinate system that can be crossed depending on the terrain, as well as the impact of various obstacles as movement modifiers and channeling of units;

- rules of direct and indirect fire and close combat, as well as fire delivering modifiers, which regulate the distances for each type of units when a direct or indirect fire occurs, as well as the distances when a close battle occurs because the modifiers determine whether and under which conditions the unit can achieve direct or indirect fire or be in close combat;

- the way in which the likelihood is carried out makes it possible to determine more precisely the probability of certain events and the way of their inclusion in the game (for example, the use of many-sided dice for playing is one of the ways of determining the likelihood of events in game theory - Figure 8);

- the hits and modifiers of the hits refer to the rules that specify when the goal is to be hit, and the different conditions that may affect the hit such as its modifiers ${ }^{14}$;

- fire radii and radius modifiers refer to the effects that can be achieved at certain distances around the target center;

- ranges and range modifiers indicate conditions that can reduce or increase radius effects, and specify the range of certain types of weapons, as well as the different conditions that may affect the increase or decrease in range;

- target effects and effect modifiers are related to the scale of effects that can be achieved on a specific target depending on the weapon used for firing a target, as well as different modifiers that can reduce or increase the effects, etc.

\footnotetext{
${ }^{13}$ Modifiers increase the detection radius if some electronic and optical devices are used, i.e. they decrease the radius due to the impacts of terrain, part of a day, meteorological conditions and the like.

${ }^{14}$ For example, range, seclusion (shelters and revetments), morals, effects in case chemical and biological weapons are used, the target movement, the unit (platform) delivering fire and the like. When it comes to the rules of hits, the rules for direct and indirect fire, as well as close combat, have to be clearly specified.
} 


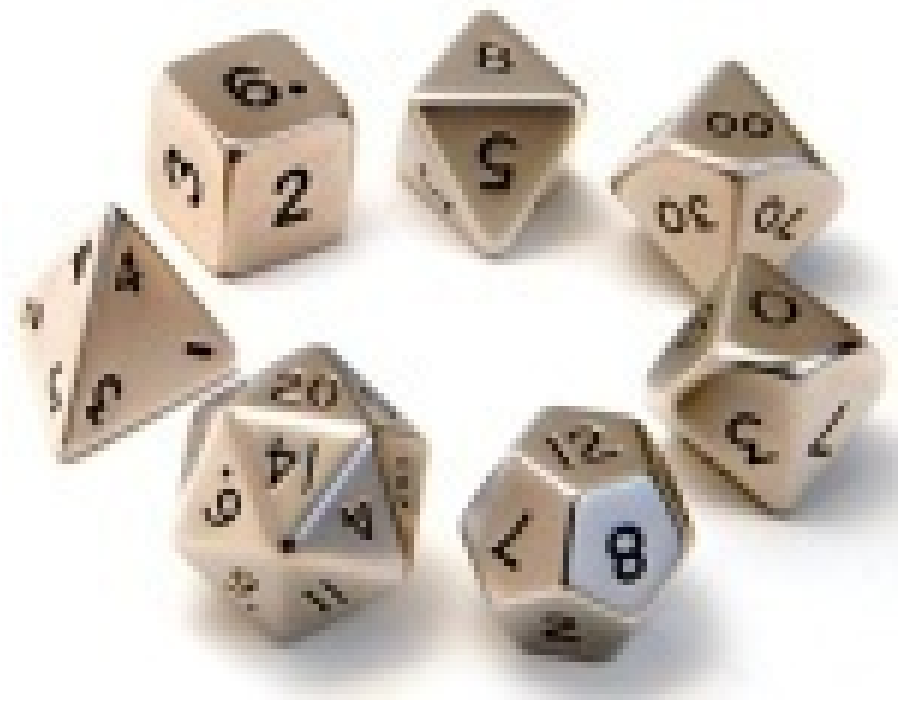

Figure 8 - Example of multi-sided dice that can include the likelihood in war games - taken (Memories from FRP, 2013)

Players are one of the required elements of a game, regardless of a model being used. Even when it comes to machine games, i.e. computer simulation, the role of a man as a player making decisions about actions to be taken is inevitable. With regard to the number of players, war games can be with one player - most often computer simulation, with two players, which is the most common war game in the military with red-blue type and with multiplayers - red, blue, allies, neutral and the like.

The analysis is an element of a war game that is inevitable for professional games, and war games should focus on the analysis itself (Perla, 1990). The analysis of war games can focus on two aspects: the decision-making process, where the analysis focus is on actions made by players; and gathering evidence of certain events, where the analysis focus is on the outcomes, i.e. the effects (Perla, 1990). For the development planning process, both analyses are important and are related to the phase of identifying the required capabilities.

The analysis needs to be timely planned and human resources have to be provided, so that it can be conducted. The analysis process consists of two parts: the data collection, which is carried out during playing war games and the collected data analysis, which is carried out after the completion of games (Perla, 1990; War Gaming Department, U.S. Naval War College, 2015). When it comes to data collection, various methods can be used, particularly observation, content analysis, testing, and operational research methods (Radinović, 1983). For the purpose of collecting data, it is necessary to develop adequate instruments to collect data on players' actions in war games and outcomes of actions taken, which are relevant for the operational planning process. 
The analysis of the collected data after completion of a war game includes the study of collected facts, data classification and categorization at a lot of levels of generality, data interpretation and data description (War Gaming Department, U.S. Naval War College, 2015).

\section{Construction of War Games}

The construction of war games is the most innovative and creative phase in the development of war games. At this stage, a large number of iterations are performed while the observed shortcomings are constantly removed in order to improve all elements of the war game. The models used during the construction of war games most often result from the requests submitted by a client, that is, by the entity that finances the project and directs the development of the war game scenario.

Taking into account the elements of war games, as well as the recommendations made in some books and related to the break-down of war game process into stages, one can conclude on the activities of the scenario construction steps when war games are used (Figure 9).

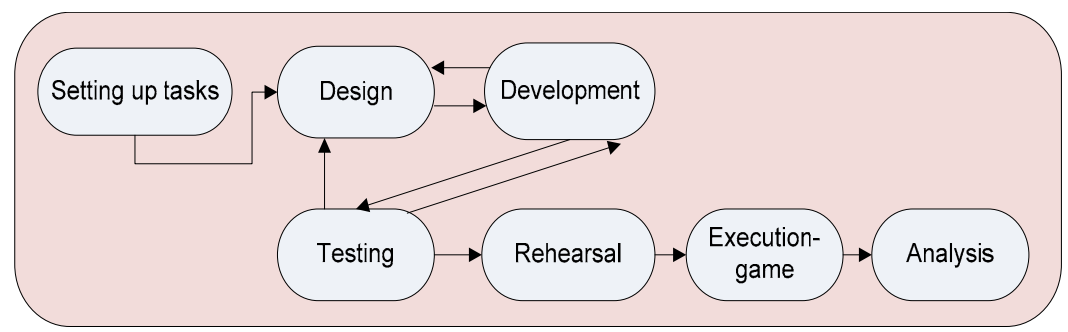

Figure 9 - Construction of scenarios using war games - taken, adapted and supplemented (United Kingdom Ministry of Defense, 2017, War Gaming Department, U.S. Naval War College, 2015)

Tasking is the first activity that determines the objectives of a war game for all players and the purpose of war games in the context of the development planning, and formulates the problem for which a war game is created. In the context of the development planning process, tasking is carried out on the basis of the phase of identifying the required capabilities, and particularly the analysis of key factors and the formulation of objectives.

The next activity is the design of a war game that primarily specifies the level of conflict, the number of players and the scenario. In this regard, the design is made on the results of the previous steps of the environment analysis and the scenario development phase, as well as during the scenario transfer. ${ }^{15}$

The development of war games refers to the activity that selects and develops models, specifies the rules of a war game, selects the methods of data collection and creates data collection instruments, determines preliminary data classification and communication in war games.

\footnotetext{
${ }^{15}$ Based on the results of the morphological analysis, where the scenarios developed by morphological analysis can be further developed in war games, or based on the results of the high-level war games.
} 
The war game testing is an activity that integrates different elements of a game and checks their compatibility, and also the design or development itself is revised in case of a need. These forms of testing are more and more represented in open sources, and first of all between players on social networks (Saković \& Terzić, 2018).

Testing refers to playing a game with real players in order to identify possible shortcomings and make the players familiar with the game.

Execution is the stage in which the game is played directly by the players following the rules of the game and making moves that produce certain outcomes.

War game analysis is the last activity of the scenario construction by war game application, by means of which the data is collected on the players' moves and outcomes of the moves and the reports are made. It is necessary to distinguish between the war game analysis and the stage of the scenario analysis, selection and interpretation. The stage of the scenario analysis, selection and interpretation requires players to try out more than one possible action in each move in order to get different scenarios based on different variants of use by both blue and red player. On the other hand, the war game analysis focuses on each individual variant of use, considering various actions taken by players and outcomes, so that the required skills can be identified. In this regard, the war games analysis needs to be made for each variant of use separately, as each will give different combinations of actions and outcomes (effects).

In addition to the scenario analysis, selection and interpretation, war game analysis data are also used to construct scenarios by using morphological analysis. The integration of the methods, which are based on war games and morphological analysis are conducted in the scenario employment (transfer) stage, when, based on the war game analysis, the parameters of the morphological analysis are formulated, and then the parameters are used in the scenario construction stage by using the morphological analysis. ${ }^{16}$ In this way, a parallel bond is established between the methods of developing scenarios by using the morphological analysis and the methods of developing scenarios by using war games.

\section{Application of War Games in the Operational Planning Process}

Due to intensive changes in the strategic environment, many countries, insisting on the collective security system, have followed the trend of reducing financial expenditures for the development of their armed forces. In contrast, investment in modern telecommunications and information technologies has significantly increased in order to develop early warning systems for potential security challenges, risks and threats. This approach has determined the development of certain software solutions in the field of defense systems in the developed countries along with the prediction of potential scenarios in case of crisis and conflict situations worldwide. Regardless of security, economic, military and other forms of confrontation between states and military alli-

\footnotetext{
${ }^{16}$ For example, a parameter of morphological analysis can be: action, reaction, counteraction, effect, target and the like, which has been identified by war games.
} 
ances, the scenarios are most often developed in the form of war games. The Republic of Serbia has the concept of total defense and military neutrality, and war games are exclusively within the framework of the employment of the armed forces, that is, in the field of engagement of the Serbian Armed Forces in order to conduct the assigned missions and tasks.

In the Serbian Armed Forces, war games are implemented in the fourth phase of the operational planning process - the analysis of employment variants. ${ }^{17}$ In principle, war games identify which employment variants can conduct tasks with minimum losses and at the same time ensure that the forces maintain the initiative and supremacy in the planned operation. According to the Instructions for Operational Planning and Work of Commands in the Serbian Armed Forces (on temporary basis), war games are conducted in the HQs of the maneuver, special, river and reconnaissance units, as well as in the HQs of joint forces in the Armed Forces, while they are not conducted in other units, where the third stage in the operational planning (the development of employment variants) is directly followed by the fifth one (the comparison of employment variants). The process of analyzing employment variants (war games) is applied at all planning levels with the aim to help the commander and headquarters - the command to come up with a method of optimum employment of the unit combat power and, at the same time, to protect its own forces with the fewest losses.

In the above-mentioned correlations of operational planning, the role of war games is seen in selecting an optimum employment variant. The war games process provides an outline of the operation course and takes place according to certain rules and clearly defined steps, with full consideration of all key factors of actions and counteractions (human, material, special and time factors). While conducting analyses, commands and $\mathrm{HQs}$ inevitably rely on doctrinal attitudes, intelligence-security and other assessments, as well as previous training and war experience. The command conducts the analysis of employment variants through the continuous action, reaction and counteraction process, with which it encourages ideas and gives the picture of the state in the operations area and the wider environment. In this way, the command, by applying war games methods, ensures that major tasks are accomplished by connecting them to the combat capabilities of its own forces.

War games test the already-developed employment variants or improve them according to the analyses performed and the latest changes made in the operational situation. This means that the commander and the command staff can change the existing employment variant or develop a new one if unforeseen critical events, tasks, demands or problems are identified. For the sake of a proper and comprehensive approach to the implementation of the fourth stage of the operational planning i.e. the analysis of employment variants, the general rules, responsibilities of the staff officers and steps during the execution of war games are defined in advance. ${ }^{18}$

\footnotetext{
${ }^{17}$ The same.

${ }^{18}$ The Instructions for Operational Planning and Work of Commands in the Serbian Armed Forces (on temporary basis), defines eight steps of war games: 1) resources raising; 2) making the list of effective forces; 3 ) making assumption lists; 4) making the list of important events and decision items; 5) selection of war games methods; 6) selection of methods for marking and presenting results; 7) playing out military operations and results assessment and 8 ) briefing on war games (not necessary).
} 
According to standard operational procedures, the operational planning process has been implemented at all command and control levels in accordance with the purpose and specifics of the Serbian Armed Forces commands and units, and thus the fourth phase of the operational planning process. When it comes to the steps of war games, the following steps deserve the special attention: work of the command during the fifth step (selection of war games techniques), the sixth step (selection of ways to record and display results) and the seventh step (the operation war-gaming and results assessment).

Within the fifth step, which refers to the choice of war games techniques, the operations officer in the command, i.e. $\mathrm{HQ}$, selects the technique to be used in the further process of operational planning in accordance with the assigned time and mission specifics. At the moment, three techniques of war games - the belt technique, the in-depth technique and the technique of critical areas (boxing technique) are used at the operational-tactical level in the Serbian Armed Forces, each of them taking into account the area of interest and all enemy forces that affect the operation outcome. These techniques can be used individually or they can be combined (General Staff of the Serbian Armed Forces, 2017).

In the sixth step of a war game referring to the selection of methods to record and display results, the $\mathrm{HQ}$, i.e. the command, writes and interprets data on the course of implementing the selected war game technique, on the basis of which it sets up the combat formation, coordinates the activities and, subsequently, makes plans or orders for the employment of units. The data are recorded through the synchronization matrix and a war games worksheet and, at the same time the employment variants are analyzed on the basis of the identified advantages and disadvantages.

Within the seventh step of a war game that refers to the operation war-gaming and results assessment, a commander and the $\mathrm{HQ}$ or the command try to predict the dynamics of combat actions, the action and reaction, and they analyze each selected event, identifying a task that the forces have to conduct at a lower level, and if necessary at two lower levels. The dynamics of war games does not decline in importance at this stage either, because the "action-reaction-counteraction" cycle continues until the important event ends or until the commander concludes that he has to change the employment variant, so that the mission can be conducted. During a war game, the command staff members analyze the risks for each employment variant, in order to obtain as realistic and objective indicators as possible. The results of the war game should provide all the elements necessary for making an appropriate decision, that is, to give answers to all essential issues and remove the majority of the commander's dilemmas.

One of key shortcomings of the existing instructions refers to the inadequate understanding and insufficient consideration of the employment variants in support units. By this approach, that is, by excluding support units from the analyses of employment variants at all planning levels, a complete operational picture of the battlefield is blurred and the conditions that can lead to making wrong decisions are created.

The role of war games in commands' operational planning process is of great importance because it represents a mechanism for checking the achieved level of the planning process and allows for the work of commands to be guided in preparing the elements, so that a commander can make a decision on timely basis. Basically, war games help the unit's commander use combat power optimally and at the same time protect the unit's strength with the fewest losses possible. The ultimate goal of war games is to select an optimal military em- 
ployment variant. A special contribution of war games is made while analyzing the employment variants of maneuver units, for whose purpose numerous software solutions have been developed. War games represent an indispensable phase in the decision-making process of the developed militaries in the world, and therefore in the Serbian Armed Forces, as well.

\section{Conclusion}

The phenomenon of war games has begun to develop since the first conflicts in the human community. Throughout history, the everlasting aspiration of a nation to dominate the other one has caused the emergence of the first strategies and tactics of warfare. These forms of conflicts have mainly been fought over the territories rich in food and water, and later in other natural resources. Human nature has remained unchanged over the centuries, so the battle for domination still goes on, and the only difference is in the mechanisms that are applied to achieve projected goals. The greatest contribution to meeting strategic objectives is provided by countries through the strength and power, which they exercise in international relations in all areas of social life, and above all through exercising political, economic and military power.

In the field of standard armed conflicts, and according to the previously established set objectives, war games are conducted at strategic, operational and tactical levels. Irrespective of the implementation level and due to intensive development of information technologies, war games start to increasingly gain importance in the field of non-conventional conflicts. They do not only have the armed character, but also the hybrid one, because they represent the combined use of state regular and irregular forces in various forms of conflict. By this approach and partial relocation of war games from the standard battlefield into the sphere of civilian environment, that is, outside the operation zone, in the premises of certain power centers, the operational picture of the battlefield becomes increasingly complex under the conditions of dynamic changes in security challenges, risks and threats, and the defense of countries becomes more and more vulnerable, especially during asymmetric conflicts. The aforementioned changes in the strategic environment are one of the main reasons for the different approaches of the majority of authors to the conceptual determination and identification of key characteristics of war games.

The elements of war games are constantly improved, first of all when it comes to technology. It often happens that software games (hobby war games) that have been developed for entertainment quickly turn into war games, which, with certain modifications, are short-listed for professional war games. The current forms of war games are more widely applied than the conventional forms of warfare, which were characteristic for the conflicts in the past century. A special contribution to the development of war games, in addition to the development of weapons and military equipment, is made by the information technology, because, through social networks, it includes all social classes, even the whole population, into asymmetric forms of conflicts.

War games are a salient phase in the decision-making process in commands and headquarters of the Serbian Armed Forces, and especially in evolution units and special units. Insufficient development of the war game elements is a key problem in the process of implementing the operational planning process. The major shortcomings can be found in tactical units and are reflected in the lack of adequate models and the failure to establish clear rules for conducting a war game. In commands and HQs of arms and service units, 
discrepancies during the implementation of the operational planning process increase, which is especially characteristic for the support units, where, along with the materialrelated, there are problems with the incomplete competence of junior commanding officers.

With regard to the development and construction of war games elements in commands and HQs of the Serbian Armed Forces, especially at the tactical level, the models showing how they should be used are not developed to the full extent because the economic base of training is slightly poor. This, to some extent, means that the ability of commands and HQs to analyze employment variants as real as possible is reduced in the operational planning process. In contrast, the conditions for the implementation of the operational planning process at the operational and strategic level are much better, primarily due to the introduction of some computer simulation, such as JCATS software, which is under the authority of the Training and Doctrine Department (J-7) of the Serbian Armed Forces General Staff.

The role of war games in the operational planning process is very important, although they are not sufficiently implemented in commands and HQs of the Serbian Armed Forces. Under these conditions, commanders of tactical units are forced to resort to improvisation and implementation of shortened work methods in the decision-making process due to the lack of adequate software solutions and models for the implementation of war games. ${ }^{19}$

By fully understanding the role of war games in the operational planning process, by training the commanding staff to implement the modern methods and management techniques, and by introducing adequate software solutions to the Serbian Armed Forces commands and $\mathrm{HQs}$, the decision-making process can be significantly improved. By this approach, the rationalization of resources and risk reduction are ensured, and units' commanders and temporary formations are provided with necessary conditions for making timely decisions.

\section{Literature}

[1] Exercise Aldershot Skirmish, (2016), Retrieved Jyн 9, 2018, from Connections UK: http://professionalwargaming.co.uk/RMASExerciseAldershotSkirmish.pdf

[2] First Battle Basic Rules, (1989), Retrieved Јун 23, 2018, from Connections UK: http://professionalwargaming.co.uk/FirstBattleRules.pdf

[3] Kahn, H., \& Mann, I. (1957), War gaming, Santa Monica: RAND corporation.

[4] KDV Technology \& Consulting, (2004-2018), Combat Table Card, Retrieved Jун 18, 2018, from GHQ: http://www.ghqmodels.com/pdf/CombatTableCard.pdf

[5] Lawrence Livermore National Laboratory, (2018), JCATS, Retrieved Jyн 10, 2018, from Conflict Simulation Laboratory: https://csl.Ilnl.gov/content/assets/docs/JCATS-LLNL-Brochure-2015.pdf

[6] Martin, J. (1982), RECON- Roleplaying Game of the Viet nam war. Retrieved from Free Wargames Rules:

http://web.archive.org/web/20031117000119/http://www.palladiumbooks.com/stuff/recon/originalrecon.pdf

[7] McHugh, F. (1966), Fundamentals of war gaming, The United States War College.

[8] Morgan, F., McLeod, G., Nixon, M., Lynch, C., \& Hura, M. (2018), Gaming space, Santa Monica: RAND Corporation.

[9] Perla, P. (1990), The art of wargaming, Annapolis: Naval institute press.

\footnotetext{
${ }^{19}$ The operational planning process at the operational-tactical level in the Serbian Armed Forces is carried out through three methods: 1) a complete work method; 2) an abridged work method with headquarters and 3) an abridged work method without headquarters.
} 
[10] Przemieniecki, J. (2000), Mathematical methods in defense analyses (3rd ed.), Redston: AIAA Education Series.

[11] Sennersten, C. (2010), Model-based Simulation Training Supporting Military Operational Processes-Doctoral Dissertation Series No. 2010:05, Blekinge: Blekinge Institute of Technology, School of Computing.

[12] Shlapak, D., \& Johnson, M. (2016), Reinforcing Deterrence on NATO's, Santa Monica: RAND corporation.

[13] United Kingdom Ministry of Defense, (2017, August), Wargaming Handbook, Retrieved Jyн 9, 2018, from Connections UK: http://professionalwargaming.co.uk/DCDC_Doctrine_UK_Wargaming.pdf

[14] War games research group, (1972), War games rules-Infantry action, Retrieved Jyн 19, 2018, from Wargames Research Group Ltd: http://www.wrg.me.ukWRG.net/History/ OLDWRG/InfantryAction.pdf

[15] War Gaming Department, U.S. Naval War College, (2015), War gamers handbook-a guide for professional wargamers, Retrieved Јун 9, 2018, from Defense Technical Information Center: http://www.dtic.mil/dtic/tr/fulltext/u2/1001766.pdf

[16] Weiner, M. (1959), An Introduction to War Games, Santa Monica: RAND corporation.

[17] Војногеографрски институт, (1971-2001), Аналогни картографрски производи, Retrieved Јун 13, 2018, from Војногеографски институт: http://www.vgi.mod.gov.rs/proizvodi/ analogni/analogni.html

[18] Војногеографрски институт, (2016), Дигитални производи, Retrieved Јун 10, 2018, from Војногеографски институт: http://www.vgi.mod.gov.rs/cirilica/proizvodi_cir/digitalni_cir/digitalni_cir.html

[19] Генералштаб Војске Србије, (2012), Доктрина операција Војске Србије, Београд: Медија центар "Одбрана".

[20] Генералштаб Војске Србије, (2015), Упутство за одређивање борбених могућности Војске Србије, Београд.

[21] Генералштаб Војске Србије, (2017), Упутство за оперативно планирање и рад команди у Војсци Србије, Београд.

[22] Ђорђевић, В. (2012, зима), Операције Војске Србије - објекат пројектног менаимента, Војно дело, Београд.

[23] Ковач, М., Дулановић, Ж., \& Стојковић, Д. (2006), Одређивање ефикасности војноорганизационих система, Београд: Војноиздавачки завод.

[24] Липтаи, С. (1996). Теоријска изграђеност тактике, Београд: Центар високих војнх школа.

[25] Митић, В., \& Петровић, Д. (2015), Модел развоја ватрене способности тактичких јединица копнене војске у извршавању задатака пробоја, SYM-OP-IS 2015 , 454-457.

[26] Мукић, Н. (2014), Теорија игара-математичке основе митова и парадокса, Нови Сад: Природно-математички факултет.

[27] Петровић, Д., Митић, В., \& Мудри, И. (2015), Вартена способност беспилотног хеликоптера наоружаног невођеним ракетним зрнима у противоклопној борби, SYM-OP-IS 2015, 450-453.

[28] Радиновић, Р. (1983), Метода ратне вештине, Београд: Војноиздавачки завод.

[29] Савезни секретаријат за народну одбрану, (1981), Тактика борбених дејстава тактичких јединица КоВ и територијалне одбране, Београд: Војноиздавачки завод.

[30] Саковић, Р., \& Терзић, М. (2018), Употреба друштвених мрежа у хибридном ратовању, Београд: Војноиздавачки завод, Војно дело бр. 7.

[31] Cећања ca FRP, (2013), Retrieved Јун 19, 2018, from Dimmypiano wordpress: https://dimmypiano.wordpress.com/2013/04/27/25/

[32] Стојковић, Д. (2017), Хибридне претње безбедности Републике Србије, Београд: Војноиздавачки завод, Војно дело бр. 6. 